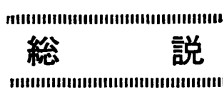

\title{
有機リン光学異性体の合成と生理作用
}

\author{
大川 秀 郎
}

住友化学工業 (株) 農薬研究部

（昭和 51 年 5 月 24 日受理）

\section{Synthesis and Biological Activity of Optical Isomers of Organophosphorus Esters}

\author{
Hideo OHKawa \\ Research Department, Pesticides Division, Sumitomo Chemical Co., Ltd., \\ Takarazuka, Hyogo 665, Japan
}

\section{はじめに}

有㙨リン化合物は 100 以上の種類があり年間 2 億ポン ド以上も生産され，殺虫剤，殺線虫剤，殺菌剤，除草剤， あるいは共力刻，昆虫避妊剤，抗ガン剤などとして広範 囲の用途に使用されている。それらの化合物の構造も木 スフォロチオエート，ジチオエート，チオレート，木ス フェート，ホスフォネート，アミデート型など様々であ るが，農薬として使用されている化合物の大部分はFig. 1 に示した一般式の範囲にはいるだろう。それらの内で

$$
\begin{aligned}
& \left.\begin{array}{l}
R \\
N H-R \\
O-R \\
S-R
\end{array}\right\} \quad \begin{array}{l}
A-P=O(S) \\
B
\end{array} \quad\left\{\begin{array}{l}
O-R \\
S-R \\
\text { Halogen }
\end{array}\right. \\
& \mathrm{R}=\mathrm{alkyl}, \operatorname{aryl}
\end{aligned}
$$

も, 殺出性有機リン酸エステル類が最も詳しく研究され て打り，その生理作用もよく解明されている1 4)。すな わち， $\mathrm{P}=\mathrm{O}$ 型の化合物はアセチルコリンエステラーゼ (Ach E) をリン酸化することによりその作用を阻害し， 神経の刺激伝達を攪乱して昆虫や哺乳動物に急性毒性を 示し，ついには死に至らしめる. $\mathrm{P}=\mathrm{S}$ 型の化合物は生体 内で mixed function oxidase (mfo) の作用を受けて, $\mathrm{P}=\mathrm{O}$ 型に变換されてその作用を現わす．殺菌性化合物 の内には細胞壁の合成を阻害するもの5)，生体内の $\mathrm{SH}$
基をアルキル化するすの6) など知られているが，いまだ 有機リン殺菌剤に共通の性質を説明できるに至っていな い. ある種の除草凨は細胞分裂を阻害するとの報告》も あるが，それのみで作用性をすべて説明できるとは思元 ない，そのほかに，ある種の有機りン共力郕が農薬の加 水分解に関与しているェステラーゼ類を阻害すること や, $\mathrm{P}=\mathrm{S}$ 型化合物が $\mathrm{mfo}$ の阻害剤であることはよく知 られている4)

一般に，これらの有機リン化合物は哺乳動物体内で mfo による種々の酸化反応打よび P-O-アリル結合の切 断, GSH S-トランスフェラーゼ類によるメチル基やアリ ル基の転位反応，エステラーゼ類による加水分解を受け てすみやかに代謝され，代謝物は短時間の内に体外に排 泄されてしまい蓄積性はないと考元られる1,2)．また，環 境下でも植物，微生物，土塞，光なぞによって加水分解， 酸化，還元反応を経て容易に分解され，残留性や生物濃 繀性の心配なく使用できる化合物群である1,8).

一般式に示した有機リン化合物は $\mathrm{A}, \mathrm{B}, \mathrm{X}$ の 3 置換 基が異なる場合にリン原子が不斉となり，光学異性体の 存在が考えられる。また，中には置換基に存在する不斉 炭素原子やスルフォキシド基に由来する光学活性体もあ る.これらの光学活性体は in vitro での酵素反応，生 物活性，哺乳動物に対する毒性および生体内代謝などに おいて，異性体間に差の見られることが多い。このよう な立体特異性は，生理活性有機リン化合物の作用機構そ の他の性質を解明する上で興味ある問題を含えでいる。 
ここでは有機リン光学異性体に 関する文献を紹介し，最近のこ の分野の研究を概観してみた w.

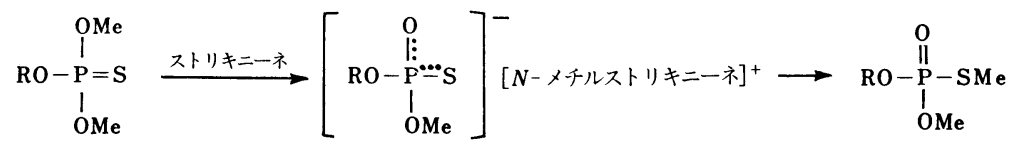

$\mathrm{R}=p-\mathrm{NO}_{2} \mathrm{C}_{6} \mathrm{H}_{4}$

\section{不斉リン原子に由来する} 光学異性体の合成

最初に光学活性リン化合物の分割に成功したのは, Meisenheimer ら (1911 年) $)^{9)}$ である。彼らは ethylmethylphenylphosphine oxide に $\alpha$-bromocamphor sulfonic acid を作用させ，生じた塩を分別結晶したのち

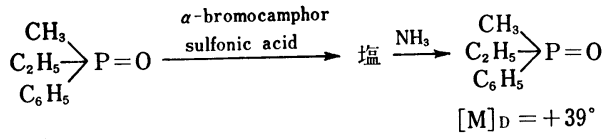

Fig. 2

にアンモニア処理することによって光学活性なホスフィ ンオキシドを得た，との後，ホスフィンスルフィド，ス ピロ第 4 ホスホニウム塩, 普通の第 4 ホスホニウム塩, ホスフィン酸エステルなど光学活性体がつぎつぎと分割 されたが，有機リン酸の光学分割はなかなか成功しなか った ${ }^{10)}$. Aaron ら (1958 年) ${ }^{11)}$ はまずアセトン中で $O-$ ethyl ethylphosphonothioic acid とキニンのジアステレ オメリック塩をつくり, 不溶性塩から（一）体を得, 次 に，ブルシンとの塩をつくって不溶性塩から（十）体を 得た. 彼らは分割したチオリン酸と 2-(ethylthio)-ethylchloride から, 光学活性なホスフォノチオレート (Fig. 3) を合成した ${ }^{12)}$ ，それ以来，同様な方法を 用いて相当数の光学活性リン酸エステル類 が合成されるようになった。

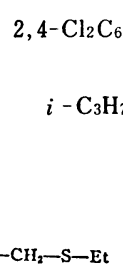

Fig. 3

有機リン酸の光学分割にはキニンやブルシンなどの天 然アルカロイド類がよく用いられるが， $\alpha$-phenylethylamine も優れた分割剤である.（十）体と（一）体の両 異性体が入手できるし，しかも天然アルカロイドに比べ て安価であり，結晶性のよい塩さえできれば大量の分割 には有利である. Wustner と Fukuto ${ }^{13)}$ は $\alpha$-phenylethylamine 它用いて $O$-2-butyl hydrogen ethylphosphonothiolate 定分割し, $O$-2-butyl S-2-(ethylthio) ethyl ethylphosphonothiolate の光学異性体を合成した。 その 他の分割方法としては，リン酸メチルエステルとストリ

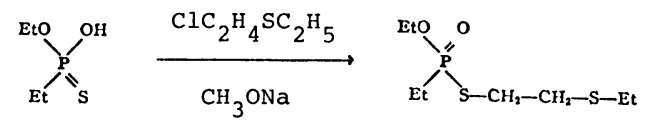

Fig. 4
に，メチルエステルの脱メチル化が起こり，N-メチルス トリキニーネができ，生じたリン酸と塩をつくる，アセ トニトリル中では $(+)$ 体の塩が多く生成し, メタノ一 ル中では（一）体の塩が主成分である。おのおのの塩を 再結晶により精製したのち，直接メチル化することによ り methylparathion の S-メチル異性体の光学活性体を 合成した (Fig. 4),

光学活性なチオリン酸からエステルを合成するには， 通常ハロゲン化アルキル $(\mathrm{RX}, \mathrm{X}=\mathrm{I}$ or $\mathrm{Br})$ を用いる. その際に，アルキル基は S 原子と反応してチオレート型 のエステルを生ずる15)(Fig. 5). 八ロゲン化アルキルの代<smiles>CP(O)(=S)O[14C](=O)O[Na]</smiles><smiles>CCC</smiles><smiles>[R7]P(C)(=O)O[14C](=O)[O-]</smiles>

$\mathrm{X}=\mathrm{I}, \mathrm{Br} \quad \mathrm{R}=\mathrm{CH}_{3}, \mathrm{C}_{2} \mathrm{H}_{5}, n-\mathrm{C}_{3} \mathrm{H}_{7}, n-\mathrm{C}_{4} \mathrm{H}_{9}, n-\mathrm{C}_{5} \mathrm{H}_{11}$

Fig. 5

わりにジアゾメタンでメチル化すると，チオレートとと もにわずかながらチオエート (P=S) も生成する. Seiber と Tolkmith ${ }^{16)}$ は, この方法でホスホロアミドチオレー トとチオェートを 10:1 の割合で得た (Fig. 6). 
オールやアミン類を反応させると，相当するジチオエー トやアミデートを与える18,19) (Fig. 8). この反応も反転

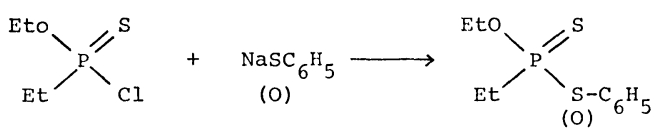

Fig. 8

を伴う。これらの方法によって各種のチオレートやチオ エート型のリン酸エステル類を合成できるが，ホスフェ ートやホスフォネートを同様な方法によって直接合成す ることは難しい. 可能な方法としては, 相当する $\mathrm{P}=\mathrm{S}$ 型 化合物を合成したのちに酸化することによって，P=O 型 に変換することである。酸化剈としては， $m$-chloroperoxybenzoic acid が優れており，反応はクロロフォルムや ジクロルメタン中で定量的に進行する.この反応は立体 保持である (Fig. 9). 酸化の際にトリクロロ酢酸などの

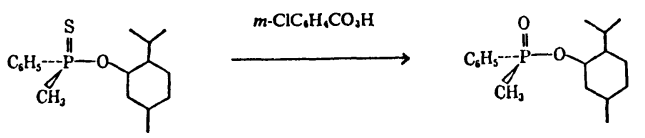

Fig. 9

強い酸が存在すると反転が起こる ${ }^{20)}$. Dyfonate ${ }^{\circledR}$ の過 酸による酸化機構は, 立体化学的に次のごとく推測され る(Fig. 10). すなわち，不斉リン化合物に過酸が求核 的に攻撃して 5 価のリン化合物Cを生ずる。このCから
$\mathrm{S}$ 原子が除かれると， D，転位が起こることによって $\mathrm{E}$ が生ずる ${ }^{19)}$. これ，な゙有機リン化合物の立体選択的合成 は偶然性が伴うと考えられがちであったが，ここに述べ た方法はかなりの一般性を有し，要領よく組み合せるこ とにより広範囲のリン酸エステル類を立体選択的に合成 できると思われる。

\section{不斉炭素原子に由来する光学異性体の合成}

リービンググループに存在する不斉炭素に基づく光学 活性リン酸エステルの合成例を付記しておきたい. diethyl malathion そ diethyl malaoxon $は$ Hassan と Dauterman ${ }^{21)}$ によって次のように合成された. l-malic acid からそのエチルェステル合成し，五臭化リンで処 理することにより (+)-diethylbromosuccinate を得た。 このブロマイドに $O, O$-diethyl potassium phosphorodithioate 它応させて (一)-diethyl malathion を得, $\mathrm{O}, \mathrm{O}$-diethyl sodium phosphorothiolate との反応で (-)diethyl malaoxon を得た. $l$-aspartic acid を亜硝酸と臭 化ナトリウムで処理すると (一)-bromosuccinic acid が得 られる。これをェチルエステルにしたのちに $O, O-\mathrm{di}-$ ethyl pottasium phosphorodithioate と反応させると $(+)-$ diethyl malathion $か$, $\mathrm{O}, \mathrm{O}$-diethyl sodium phosphorothiolate との反応で (+)-diethyl malaoxon が得られる (Fig. 11-I). 筆者 ${ }^{22)}$ は papthion と papoxon の光学活 性体を次のように合成した。 D-(-)-と L-(+)-mandelie acid をおのおのエチルエステルにし，チオニルブロマイ

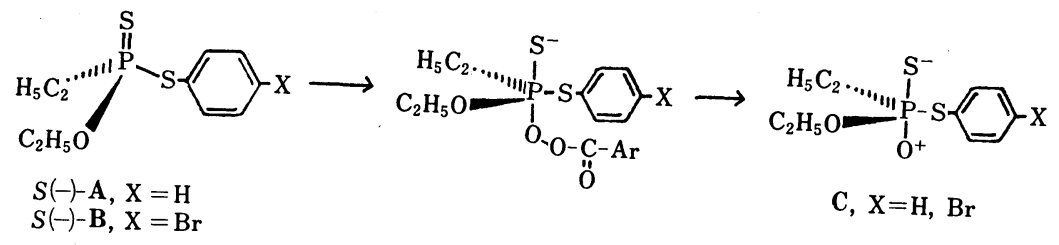

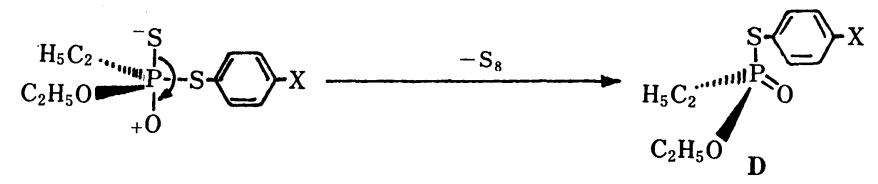

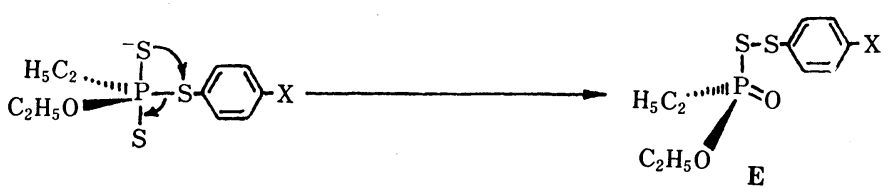

Fig. 10 


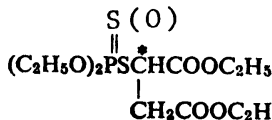

( I )

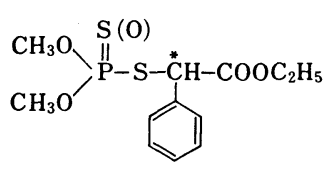

(II)
Fig. 11

ドでブロム化する，得られたブロマイドを sodium dimethylphosphorodithioate と反応させると papthion が, また， sodium dimethylphosphorothiolate との反応で papoxon が得られた ${ }^{11)}$ 。これらの反応過程では，ブロム 化とリン酸を結合する段階でおのおの反転が起きる.

\section{光 学 純 度}

有機リン光学活性体の旋光度は, 測定条件によって变 わることがある。たとえば, phosphoroamidothioate (Fig. 12）をべンゼンに溶かし $589 \mathrm{~m} \mu$ で測定すると $-23.4^{\circ}$ であったが、メタノール中で は $0^{\circ}$ であった。メタノール 溶液を濃縮して再びベンゼン 中で測定すると，元の旋光度 を示した。したがってメタノ ール中でラセミ化したのでは なく，打そらく不斉冺原子 に直結した $\mathrm{NH}$ 基の水素結

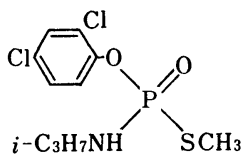

$[\alpha]_{\mathrm{D}}-23.4^{\circ}$ (benzene) $0^{\circ} \quad$ (methanol)

Fig. 12
合性がこの化合物の旋光性や立体配置に強く影響してい ると考えられる16.

合成した化合物の化学的純度は, 薄層クロマトグラフ ィーやガスクロマトグラフィーで簡単にチェックできる が，旋光度が小さくしかも標品の得られない化合物の光 学純度を測定することは容易でない，比較的よく用いら れるのは，NMR の測定である，化合物 I とII (Fig. 13)

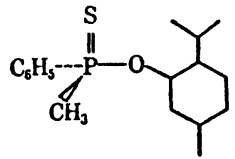

( I )

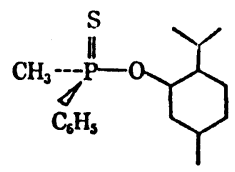

(II)
Fig. 13

の場合, $\mathrm{P}-\mathrm{CH}_{3}$ と $\mathrm{C}-\mathrm{CH}_{3}$ はおのおのダブレットのシグ ナルを与えるが, Table 1 に示したようにケミカルシフ

Table 1

\begin{tabular}{ccc}
\hline \multirow{2}{*}{ Compound } & \multicolumn{2}{c}{$\delta$} \\
\cline { 2 - 3 } & $\mathrm{P}_{-} \mathrm{CH}_{3}$ doublet & $\mathrm{C}-\mathrm{CH}_{3}$ doublet \\
\hline I & 1.87 & $0.70-1.02$ \\
II & 1.93 & 0.40 \\
\hline
\end{tabular}

トに差があることを利用して両異性体の比を測ることが できる ${ }^{20)}$. 光学活性なシフト試薬を使用した NMR の測 定で成功した例もある。 $O$-ethyl $O$-methyl methylphosphonate (I) (Fig. 14) の NMR を重クロロフォルム中

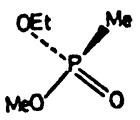

( I )

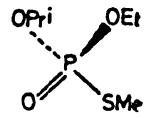

(II)
Fig. 14

で tris-[3-(heptafluoro- $\boldsymbol{n}$-propylhydroxymethylene)- $(+)-$ camphorato] europium (III) の存在下で $60 \mathrm{MHz}$ で測定 すると $\mathrm{P}-\mathrm{O}-\mathrm{CH}_{3}$ はダブレットシグナルを示すが，ラセ ミ体では一対のダブレットを示しその差は $3 \sim 6 \mathrm{~Hz}$ であ る。この差に基づいて両異性体の混合比を測定した結果 は，旋光度から推定した值とよく一致した ${ }^{23)}$. しかし， (S)-O-ethyl $O$-isopropyl S-methylphosphorothiolate (II) では $\mathrm{P}-\mathrm{S}-\mathrm{CH}_{3}$ のシグナルのシフト差が両異性体間で小 さく(約 $1 \mathrm{~Hz})$ ，よい結果が得られなかった。特殊な例 であるが，異性体間の酵素阻害度の差を利用して光学純 度を測定した例もある ${ }^{24)}$.(一)-sarin

(Fig. 15) は（+)-sarin に比べて Ach E 阻害度が 4, 200 倍も強い。この ような両異性体間の酵素阻害度の大き

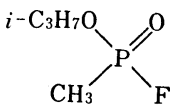

Fig. 15 な差に基づき合成品の光学純度を計算したところ, 標品 の旋光度から求めた純度とよく一致した。

\section{絶 対 構 造}

反応機構を立体化学的に解明するには，化合物の絶対 構造を明らかにする必要がある. Allahyari は Dyfonate® ホモログの光学異性体の絶対構造を，X線回折法によっ て決定した ${ }^{19)}$. Dyfonate®それ自身は液体であるが，そ の p-ブロモ体 (Fig. 16-A) は結晶 (mp $\left.31.5^{\circ} \mathrm{C}\right)$ を与.

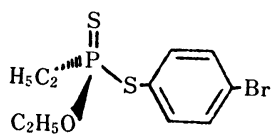

$S-(-)-\mathbf{A}$

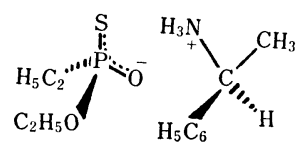

$$
S_{\mathrm{p}}-(-), S_{\mathrm{c}}-(-)-\mathbf{B}
$$

Fig. 16
え，X線回折法による絶対構造の決定が可能であった。 また, $O$-ethyl ethylphosphonothioic acid のアミン塩 (Fig. 16-B) も同様に絶対配置が決められた。彼らはこ れらの結果をもとに，Dyfonate®の酸化反応機構を立体 化学的に解明しょうと試みた。すなわち, Dyfonate 


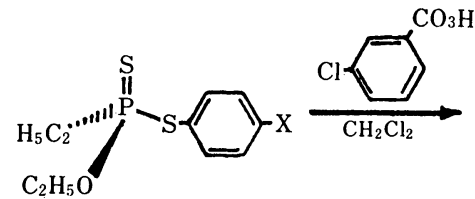

$S(-)-\mathbf{A}, \mathrm{X}=\mathrm{H}$

$S(-)-\mathrm{B}, \mathrm{X}=\mathrm{Br}$

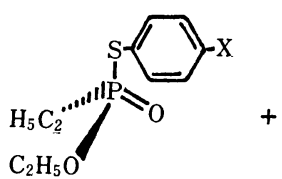

$S(-)-\mathrm{C}, \mathrm{X}=\mathrm{H}$

$S(-)-\mathrm{D}, \mathrm{X}=\mathrm{Br}$

Fig. 17

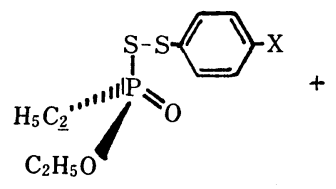

$S(-)-\mathbf{E}, \mathrm{X}=\mathrm{H}$

$S(-)-\mathrm{F}, \mathrm{X}=\mathrm{Br}$

(Fig. 17-A) とその p-ブロモ体の (一) 異性体 (Fig. 17B)を $m$-chloroperoxybenzoic acid で酸化すると (一) 体

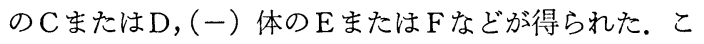
れら生成物の絶対配置は, 既知化合物 Fig. $16 S_{p-(-)}$ B に誘導したり，Fig. $16-S_{p}$-(一)-B から生成物を合成 することにより， S配位と決められた。

（注）私信によれば, 最近, Fukuto らは Dyfonate 光 学異性体の $m$-chloroperoxybenzoic acid による oxon 体への酸化が立体保持で進行するという以 前とは逆の結果を得ている.

\section{コリンエステラーゼ (ChE) 阻害と殺虫性}

酵素が不斉炭素を有する化合物（基質または阻害剮） との反応において立体特異性を示すことはよく知られて おり，そのような立体特異性は酵素表面あるいは活性中 心の不斉性に由来すると考光られる。神経の刺激伝達に 関与しているアセチルコリンエステラーゼ (AchE) は, その本来の基質であるアセチルコリンが光学活性でない にもかかわらず，光学活性な基質や阻害郕との反応にお いて立体特異性宗す。

Aaron ら ${ }^{12}$ は $O$-ethyl S-2-(ethylthio) ethyl ethylphosphonothiolate (Fig. 18) の光学異性体を合成して 4 種の $\mathrm{ChE}$ 類との反応性を測定した. (一) 体は $(+)$ 体に比べて電気ウナギ, 人赤

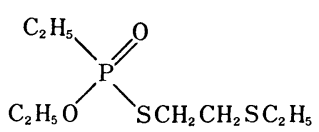

Fig. 18

血, 球子牛赤血球の AchE および馬血清 の $\mathrm{ChE}$ に対して 10 倍から 20倍も反応 性が高かった。つまり，4種の $\mathrm{ChE}$ 類 は不斉リン原子に由来する有機リン光学 異性体との反応に扔いて，明らかな立体 特異性を示したのである. Fukuto と Metcalf ${ }^{25)}$ は, 上記光学異性体の昆虫に 対する毒性をテストした。 (一) 体は (+) 体に比べてイエバエに 6 倍，力に 10 倍，
ミッバチに対して9倍の強い殺虫力を示した。また， (一)体はイエバエ頭の AchE 阻害も (+)体に比べて 11 倍ほど強力であり。殺虫性の結果とよく一致した。

哺乳動物に対する毒性については Hilgetag と Lehman ${ }^{14)}$ の報告があり， methylparathion の S-異性体で ある $O$-methyl S-methyl $O$-4-nitrophenylphosphorothiolate の（一）体はラットに対して (+) 体よりも5 倍ほど強い急性毒性を示した。 これらの結果から, 有機 リン光学異性体と $\mathrm{ChE}$ 類との in vitro での反応, 昆 虫および哺乳動物に対する毒性においてはっきりと立体 特異性の存在が証明されたわけである。

Ooms と Boter ${ }^{15,26)}$ は一連の S-alkyl p-nitrophenyl methylphosphonothiolates $に$ 関して, ChE 類の阻害や八゚ ラオキンナーゼによる加水分解反応における立体特異 性, つまり (一) 体と (+) 体の活性比 $\left(\mathrm{r}_{\mathrm{a}}=(-)\right.$ 体の 活性/(十) 体の活性)，にアルキル基の大きさがどのよう に影響する少を系統的に研究した。ささらに，キモトリプ シン，トリプシン，アリエステラーゼなどの加水分解酵 素についても同様な案験を行なった. 使用した䤃素類は おのおの一連の光学異性体に対して多少なりとも立体特 異性を示し，ラセミ体の活性法両異性体の中間であった (Table 2)。それらの酵素の内, $\mathrm{ChE}$ 類は (一) 体で阻

Table 2 Ratios of activity $\left(\mathrm{r}_{\mathrm{a}}\right)$ of enantiomers of S-alkyl p-nitrophenyl methylphospohnothiolates, (RS) $\mathrm{MeP}(\mathrm{O}) \mathrm{OC}_{6} \mathrm{H}_{4} \mathrm{NO}_{2}$.

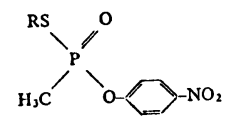

ratios of activity $\left(\mathrm{r}_{\mathrm{a}}\right)$

\begin{tabular}{llcccc}
\hline \multicolumn{1}{c}{ Enzyme $\mathrm{R}=$} & $\mathrm{CH}_{3}$ & $\mathrm{C}_{2} \mathrm{H}_{5}$ & $n \mathrm{C}_{3} \mathrm{H}_{7}$ & $n \mathrm{C}_{4} \mathrm{H}_{9}$ & $n \mathrm{C}_{5} \mathrm{H}_{11}$ \\
\hline Acetylcholinesterase & 1.2 & 13.1 & 36.4 & 50.5 & 29.1 \\
Butyrylcholinesterase & 0.66 & 0.86 & 2.0 & 2.9 & 1.0 \\
Paraoxonase & 0.81 & 0.26 & 0.19 & 0.27 & 0.06 \\
Aliesterase & 2.2 & 0.15 & 0.52 & 0.72 & 0.21 \\
Acetylesterase & 8.9 & 49 & 42 & 125 & 540 \\
Chymotrypsin & 0.07 & 0.29 & 2.1 & 2.8 & 6.9 \\
Trypsin & 0.66 & 1.5 & 3.0 & 1.4 & 2.7 \\
\hline
\end{tabular}

$\mathrm{r}_{\mathrm{a}}=$ activity of $(-)$-isomer/activity of $(+)$-isomer. 
害されやすく，しかも AchE のほうがブ チリルコリンエステラーゼ (BuChE) よ りも大きな立体特異性を示した. AchE の $\mathrm{r}_{\mathrm{a}}$ 值は $n$-ブチルホモログで最大 (50) であり, $\mathrm{BuChE}$ むはり $n$-ブチルで最 大（3）であった。 パラオキソナーゼも, これら光学異性体の加水分解に扔いて大 きな立体特異性を示し, $\mathrm{r}_{\mathrm{a}}$ 值は $n$-ペン チルホモログで最大であった。つまり， AchE とは逆に $(+)$ 体が早く水解され， しかもアルキル基が大きくなるほど立体 特異性も大きくなる，アセチルエステラ 一ゼは使用した酵素の内で最も著しい立 体特異性を示し， $\mathrm{r}_{\mathrm{a}}$ 值はアルキル基が大 きくなるにつれて増大した。 アリエステ ラーゼ，キモトリプシン，トリプシンも 立体特異性を示したが，アルキル基の大 きさによってその効果は変化した。つま り，アリエステラーゼの場合はアルキル 基が小さいとき（一）体が，大きくなる そ（十）体の作用が強い。キモトリプシ ンとトリプシンは逆にアルキル基が小さ いとき（十）体が，大きくなると（一） 体の反応性が高くなる。これらの事実か ら酵素の種類，有機リン刘のアルキル基 の大きさによって示される立体特異性も 大きく变化することが明らかであろう。

Wustner と Fukuto ${ }^{13)}$ は 2 個の不斉中 心（リン原子とアルキル基の炭素）を持 $\supset O$-2-butyl S-2-(ethylthio) ethyl ethylphosphonothiolate (demeton アナログ) の光学異性体 4 種を合成し, ChE 類の阻 害効果，昆虫やマウスに対する毒性打よび浸透殺虫性を テストし，生理活性に打ける不斉リン原子と $\alpha$-炭素原 子の役割を推察した。イエバェ頭と子牛赤血球の AchE および馬血清の ChE に対する 4 異性体の阻害効果には, 大きな差が見られた。たとえば，イエバエ頭の AchEに

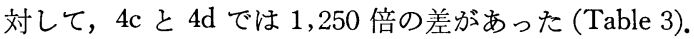
阻害力の差はリンに由来する異性体間で大きく，(一)体 は $(+)$ 体よりも強力であった。 $\alpha$-炭素の不斉性の効果 はリン原子と比べて小さく，阻害力の異性体間の差はわ ずかであったまた， 3 種の $\mathrm{ChE}$ に対する 4 異性体の 阻害力は $4 \mathrm{a}>4 \mathrm{~d} \gg 4 \mathrm{f}>4 \mathrm{c}$ の順序であった。つまり，こ れらの光学活性阻害剂は 3 種の $\mathrm{ChE}$ の活性中心と同じ
Anticholinesterase properties of 4 and its resolved isomers against housefly head acetylcholinesterase (HFAChE), bovine erythrocyte acetylcholinesterase (BAChE), and horse serum cholinesterase (HSChE).<smiles>CCCCCCCCCCCCC</smiles>

\begin{tabular}{|c|c|c|c|c|c|c|c|}
\hline \multirow{2}{*}{ No. } & \multicolumn{2}{|c|}{$\begin{array}{l}\text { Configu- } \\
\text { ration }\end{array}$} & \multirow{2}{*}{\multicolumn{2}{|c|}{$\begin{array}{l}\text { HFAChE, } \\
k_{i}(95 \% \mathrm{Cl}) \\
\left.\mathrm{M}^{-1} \mathrm{~min}^{-1}\right) \\
\times 10^{-3}\end{array}$}} & \multirow{2}{*}{\multicolumn{2}{|c|}{$\begin{array}{c}\mathrm{BAChE}, \\
k_{i}(95 \% \mathrm{Cl}) \\
\mathrm{M}^{-1} \mathrm{~min}^{-1} \\
\quad \times 10^{-3}\end{array}$}} & \multirow{2}{*}{$\begin{array}{l}\text { HSChE, } \\
k_{i}(95 \% \mathrm{Cl}) \\
\mathrm{M}^{-1} \mathrm{~min}^{-1} \\
\quad \times 10^{-3}\end{array}$} \\
\hline & $\alpha-\mathrm{C}$ & $\mathrm{P}$ & & & & & \\
\hline 4 & \multicolumn{2}{|c|}{ Racemic } & 969 & (29) & 31.8 & $(0.9)$ & $5.95 \quad(0.21)$ \\
\hline $4 \mathrm{a}$ & + & - & 1,710 & (50) & 65.3 & $(2.1)$ & $(0.9)$ \\
\hline $4 c$ & + & + & & $5(0.02)$ & $0.62 \mathrm{~s}$ & $(0.020)$ & $0.483(0.042)$ \\
\hline $4 d$ & - & - & 1,690 & (110) & 54.5 & $(2.2)$ & $6.85 \quad(0.30)$ \\
\hline $4 \mathrm{f}$ & - & + & & $2(0.30)$ & 1.45 & $(0.07)$ & $1.01 \quad(0.18)$ \\
\hline
\end{tabular}

Table 4 Toxicity of the optical isomers of $O-2$-Butyl S-2-(Ethylthio) ethyl ethylphosphonothioate (4) to houseflies (topical, adult, female), mosquito larvae, and white mice (oral).

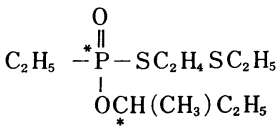

\begin{tabular}{|c|c|c|c|c|c|c|}
\hline \multirow{2}{*}{ No. } & \multicolumn{2}{|c|}{ Configuration } & \multicolumn{2}{|c|}{ Musca domestica } & \multirow{2}{*}{$\begin{array}{c}\text { Culex } \\
\text { larvae, } \\
\text { LC }_{50} \mathrm{ppm}\end{array}$} & \multirow{2}{*}{$\begin{array}{c}\text { Mouse 우, } \\
\mathrm{LD} D_{50} \\
\mathrm{mg} / \mathrm{kg}\end{array}$} \\
\hline & $\alpha-\mathrm{C}$ & $\mathrm{P}$ & $\begin{array}{l}\text { NAIDM, } \\
\text { LD }_{50} \mu \mathrm{g} / \mathrm{g}\end{array}$ & $\begin{array}{c}\mathrm{SC} \\
\mathrm{LD}_{50} \mu \mathrm{g} / \mathrm{g}\end{array}$ & & \\
\hline 4 & \multicolumn{2}{|c|}{ Racemic } & 10.8 & 78 & 0.65 & 3.1 \\
\hline $4 a$ & + & - & 6.7 & 33 & 0.25 & 3.2 \\
\hline $4 \mathrm{~b}$ & + & \pm & 9.4 & 84 & 0.66 & \\
\hline $4 c$ & + & + & $>500$ & $>500$ & $>1$ & 110 \\
\hline $4 d$ & - & - & 6.9 & 42 & 0.15 & 2.8 \\
\hline $4 \mathrm{e}$ & - & \pm & 12.1 & 122 & 0.57 & \\
\hline $4 \mathrm{f}$ & - & + & $>500$ & $>500$ & $>1$ & 125 \\
\hline
\end{tabular}

ように反応し，しかもおのおのの酵素の立体特異性も類 似していると考えられる。一般に昆虫や哺乳動物に対す る有機リン剂の毒性は，それらの AchE 阻害力と平行関 係にある，4異性体の内，AchE の強い阻害剂であった 4a と 4d はイエバエとマウスに対する毒性が高く，弱い 阻害剂 $4 \mathrm{c}$ と $4 \mathrm{f}$ の毒性は低い. とくに，マウスに対す る毒性と AchE 阻害の間にはきわめて良い相関性が見ら れた (Table 4)。したがって，マウス体内では解毒に関 与する代謝や浸透性は両異性体の間でほとえど同じと考 えられる，4異性体の植物浸透殺虫力テストの結果もや はりリン (-) 体が強く，リン $(+)$ 体はほとんど活性 を示さなかった，植物体内での移行性などに影響する々 
思われる物理化学的性質に関しては異性体間で差はない と考えられるので, リン (-) 体の強い作用はAchE の 強い阻害力に基べくと思われる，興味あることに，リン （一）体（4a と 4d) の効力はラセミ体よりも約 3 倍も長 く持続した。つまり，浸透性殺蝓としてリン（一）体 はラセミ体よりも優れていることになり，今後実用面で の研究が期待される.

Wustner と Fukuto ${ }^{27)}$ の研究をもう一つ紹介したい. 彼らは絶対構造の解っている 4 光学異性体 (リンと炭素 に不斉中心ある)（Fig. 19）を合成し，ChE 類の立体特

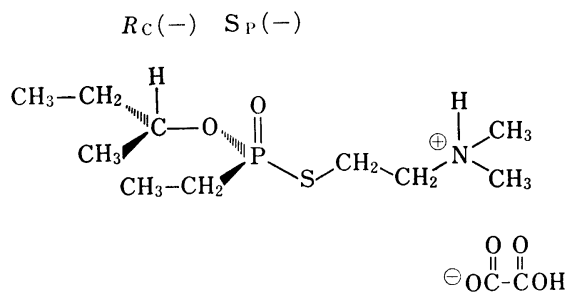

Fig. 19

異性を速度論的に解析した。 $S_{p}$ 配置を持つ異性体は $R_{p}$ 異性体よりも強い阻害剂であり，子牛赤血球 AchEに対 して 1,630 倍，イエバェ頭の AchEに 9,120 倍, 馬血 清の ChE に 40 倍の差を示した。 $S_{p}$ 異性体の立体化 学的特異性は醉素々の高い親和性 $\left(k_{a}\right)$ と早いリン酸化 反応 $\left(k_{p}\right)$ に起因している。炭素不斉性の阻害効果に及 ぼす影響は，リン原子に比べて小さい，いずれにせよ酵 素阻害 $\left(k_{i}\right)$ だけでなく醉素との親和性 $\left(k_{a}\right)$ とリン酸化 反応 $\left(k_{p}\right)$ も阻害凨の立体化学的性質に影響されること が明らかである。

有機りン酸エステルのリービンググループに存在する 炭素の不斉性が生理活性にどの程度影響するかについて は, Dauterman $ら^{21,28)} の$ diethyl malathion と diethyl malaoxon (Fig. 11-I) に関する研究がある. diethyl malathion と diethyl malaoxonの $(+)$ 体はマウスとイエバ エに対して (一) 体よりも約 2 倍ほど強い毒性を示した。 また，(+)-diethyl malaoxon は in vitro で (一) 体よ りも AchEとカルボキシエステラーゼを強く阻害した. したがって，(+) 体の強い毒性は (+)-diethyl malaoxon による強い AchE の阻害の結果と考元られるが，(+)diethyl malaoxon の強いカルボキシエステラーゼ阻害も malathion と malaoxon の水解を抑制することにより $(+)$ 体の毒性を高めていると考えられる。

筆者ら ${ }^{22)}$ は malathion 々同様にリービンググループの $\alpha$-炭素が不斉である papthion と papoxon (Fig. 11-II) の異性体を合成して種々の昆虫やマウスに対する毒性を テストした。(+)-papthion はカ (幼虫, 成虫), 二カメ イチュウ (幼虫)，コナガ (幼虫) およびマウスに対して （一）体上りも強い毒性を示した。 それとは逆に，イエ バェ（成虫）では（+）体より（一）体のほうが強力で あった (Table 5)。これらの結果は in vitro における papoxon 異性体の AchE 阻害効果とよく一致した (Table 6). 炭素の不斉性はリン原子と比べると in vitro におけ

Table 5 Toxicity of (+)-, (-)- and ( \pm )-papthion to houseflies (adult), mosquitoes (adult, larva), rice stem borers (larva), diamond back moths (larva) and white mice.

\begin{tabular}{|c|c|c|c|}
\hline \multirow{2}{*}{ Animal } & \multicolumn{3}{|c|}{$\begin{aligned} \mathrm{LD}_{50} & \left(\mu \mathrm{g} / \text { insect or } \mathrm{mg} / \mathrm{kg}^{\mathrm{a})}\right) \\
& \text { or } \mathrm{LC}_{50}(\mathrm{ppm})^{\mathrm{b})}\end{aligned}$} \\
\hline & $\begin{array}{l}(+)- \\
\text { Papthion }\end{array}$ & $\begin{array}{l}(-)- \\
\text { Papthion }\end{array}$ & $\begin{array}{l}( \pm)- \\
\text { Papthion }\end{array}$ \\
\hline \multicolumn{4}{|l|}{ Housefly } \\
\hline Lab-em-7-em (소우) & 0.054 & 0.028 & 0.042 \\
\hline WHO (우) & 0.076 & 0.030 & 0.051 \\
\hline \multicolumn{4}{|l|}{ Mosquito } \\
\hline Adult & 0.0028 & 0.0069 & 0.0042 \\
\hline Larva & $0.0042^{\mathrm{b})}$ & $0.0085^{b)}$ & $0.0051^{b)}$ \\
\hline Rice stem borer & 0.022 & 0.109 & 0.064 \\
\hline Diamond back moth & $37^{\mathrm{b})}$ & $66^{\mathrm{b})}$ & $40^{\mathrm{b})}$ \\
\hline Mouse (ip) & $105^{a)}$ & $290^{\text {a })}$ & $152^{a)}$ \\
\hline
\end{tabular}

Table 6 Anticholinesterase activity of $(+),(-)-$ and $( \pm)$-papoxon against bovine erythrocyte acetycholinesterase, housefly head acetylcholinesterase and rice stem borer larva acetylcholinesterase.

\begin{tabular}{cccc}
\hline \multirow{2}{*}{ Compound } & \multicolumn{3}{c}{$\mathrm{I}_{50}(\mathrm{M})$} \\
\cline { 2 - 4 } & $\begin{array}{c}\text { Bovine } \\
\text { erythrocyte }\end{array}$ & $\begin{array}{c}\text { Housefly } \\
\text { head }\end{array}$ & $\begin{array}{c}\text { Rice stem } \\
\text { borer }\end{array}$ \\
\hline (+)-Papoxon & $8.4 \times 10^{-9}$ & $8.4 \times 10^{-10}$ & $8.0 \times 10^{-9}$ \\
(-)-Papoxon & $2.5 \times 10^{-8}$ & $4.7 \times 10^{-10}$ & $1.9 \times 10^{-8}$ \\
(土)-Papoxon & $1.5 \times 10^{-8}$ & $6.5 \times 10^{-10}$ & $1.0 \times 10^{-8}$ \\
\hline
\end{tabular}

る酵素反応拉よび昆虫や哺乳動物に対する毒性にはとれ ほど大きな影響を及ぼさないかもしれないが，酵素や昆 虫の種類を变えると異性体間で微妙な差が見られること から，広範囲の酵素や昆虫に対してテストすることによ り，たとえば酵素の活性中心の微細な相異を識別できる かもしれない. また, 通常, AchE は数種のアイソザイ ムから成り立っているので, 昆虫の種類によっては生理 的に重要なアイソザイムのみを光学異性体によって選択 的に阻害できる可能性もあるだろう. 


\section{殺草性}

殺草活性を有する有機リン化合物は数多く知られてい るが，ここでは良く似た構造古持つ 2 種のホスホロアミ ドチオエートの光学異性体の殺草活性について取り上げ てみたい。除草剂 DMPA (Fig. 20-I) の不斉リン原子に

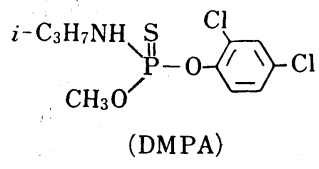

( I )<smiles>CCCCCNP(=S)(OCC)Oc1cccc([N+](=O)[O-])c1</smiles>

( II )
Fig. 20

由来する光学異性体は Seiber と Tolkmith $\left.{ }^{15}\right)$ にって 合成され，それらの殺草活性は Holmsen ${ }^{29)}$ によってテ ストされた。 fescue に対する生育阻害試験の結果，50\% 生育阻害濃度は (一) 体で $1.5 \mathrm{ppm}$ ，ラセミ体で $4.0 \mathrm{ppm}$, (+) 体では $36.5 \mathrm{ppm}$ であった。つまり,(一) 体は $(+)$ 体よりも約 24 倍, ラセミ体より 2.7 倍強力であった。筆 者ら ${ }^{18)}$ は $O$-ethyl $O$-2-nitro-5-methylphenyl $N$-isopropyl phosphoroamidothioate (Fig. 20-II) の光学異性体 を合成し，殺草活性をテストした。 ヒエに対する $50 \%$ 生育阻害濃度は (+) 体で $1.07 \times 10^{-7} \mathrm{M},(-)$ 体で 3.14 $\times 10^{-8} \mathrm{M}$ であり，イネに対しては（+）体が $1.89 \times 10^{-6}$ $\mathrm{M} （-）$ 体が $5.19 \times 10^{-7} \mathrm{M}$ であった。、いずれに対して も，(一) 体のほうが $(+)$ 体よりも 3.4 3.6 倍ほど強 く, ラセミ体の活性は両者の中間であった。イネやヒエ による根からの吸収量および植物体内での分解速度に関 しては，両異性体間でほとえど差がない33)ことから作用 点での感受性の差が考えられるが，現時点ではこれら化 合物の作用機構はほとえど解明されていない。

\section{殺菌性}

Tolkmith $5^{30,31)}$ は有機リン光学異性体を合成し，そ れらの殺菌効果をテストしたが，Fig. 21 に示した化合
物は植物病原菌である Erysiphe cichoracearum \& Phytophthora infestans に対する効力が弱く, 光 学異性体間の差は認められなかっ た。しかし，マウスに対する急性 毒性関しては, $(+)$ 体が $(-)$

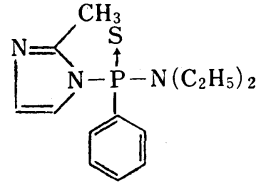

Fig. 21 体やラセミ体に比べて約 2 倍の大きな $\mathrm{LD}_{50}$ 值を示した. これまでに有機リン光学活性体の殺菌効果をテストした 例は少ない，今後，種々の化合物について多種の病原菌 に対してテストしたり，あるいはテスト方法を工夫する ことによって立体選択性を証明できるだろう。

\section{代謝}

農薬ではないが抗ガン郕として有名な cyclophosphamide (Fig. 22) は，不斉リン原子它有することから鏡像

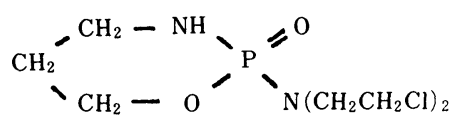

Fig. 22

体の存在が考光られる。Cox ら ${ }^{32}$ 怕ラセミ体 $1 \mathrm{~g}$ 学 3 人 の患者に服用した後 24 時間の尿から，1人当たり $9.5 \sim$ $17.5 \mathrm{mg}$ の左旋性の cyclophosphamide 劣得た。 その後, 彼らは光学異性体を合成した，標品の旋光度から推測す ると，患者の尿から得たサンプルは 83 91\%の ( - 体 を含えでいることになる，合成した異性体の抗ガン作用 をマウスの ADJ/PC6 血漿細胞腫瘍に対してテストした 結果, (一) 体は $(+)$ 体よりも殺腫瘍細胞作用が強力であ った。これらの事実から, cyclophosphamide は人体内で 立体選択的に代謝されるとともに，光学異性体間で抗腫 瘍作用に差があることが明らかである。

筆者らは先に述べたように有機リン光学異性体（Fig. 20-II）の殺草性をテストしたが，引き続きそれら光学異 性体のウサギ肝臓 mfo による代謝を検討した ${ }^{33)}$. (+), （一）およびラセミ体を它おの打のウサギ肝マイクロソー<smiles>CCOP(=O)(NC(C)C)Oc1cccc([N+](=O)[O-])c1</smiles><smiles>CCOP(=S)(NC1CCCCC1)Oc1ccccc1[N+](=O)[O-]</smiles>

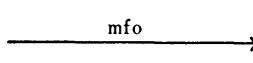

$+$

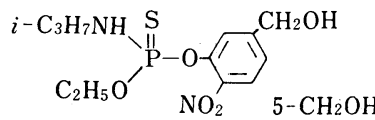

Fig. 23 
ム-NADPH系と反応させると種々の代謝物を与えるが， その内の主成分は oxon 体と 5- $\mathrm{CH}_{2} \mathrm{OH}$ 体であった (Fig. 23)。両代謝物の生成率は（+）体で $9.2 ， 4.4 \% ，(-)$ 体で 8.3，5.3\%，ラセミ体では $14.9 ， 5.5 \%$ であり， 異性体間で差はほとえぞ認められなかった。 この反応条 件下で母化合物の残存量は (+) で 8.3, (-) で9.1, ラ 七ミでは $21 \%$ であり, ラセミ体の代謝速度は $(+)$ 体 や（一）体と比べてわずかに遅いと思われる。また，得 られた主代謝物 oxon と $5-\mathrm{CH}_{5} \mathrm{OH}$ 体の旋光性は母化合 物に支配されており，(+) 体からは (+)の，(）体か らは（一）の，ラセミ体からはラセミの両代謝物が得ら れた。 また, 得られた (+), (-) oxon 体の旋光度は $m$ chloroperoxybenzoic acid による酸化で得た標品とほぼ同 ビであったしたがって，mfokよる $\mathrm{P}=\mathrm{S} の \mathrm{P}=\mathrm{O}$ へ の酸化は立体保持であると推測される。しかし，これら の酸化機構を解明するためには, 絶対構造を明らかにす る必要があらう。 oxon 型光学異性体の子牛赤血球 $\mathrm{AchE}$ 阻害を測定した結果，(一) oxon 体のほうが (十)体より も 7.5 倍ほど強力であった。 oxon 体の生成率には差はな いが，それらの AchE 阻害体内には立体特異性が見られ た.

有機リン剂やカーバメート骫でスルフィド基を持つ化 合物は, 哺乳動物や微生物の mfo によってスルフォキ シドに酸化され，スルフォキシド体のほうがより強力な 生理活性を示すことがある ${ }^{34,35)}$. 他方, 分子にスルフォ キシド基が導入されると分子不斉となり，鏡像体の存在 が考えられる。スルフィド基を持つ有機リン殺線虫㓮 phorate (Fig. 24-I) は線虫, バクテリヤおよび菌によっ

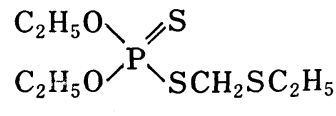

( I )

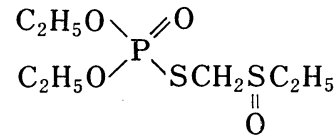

( II )
Fig. 24 Phorate (I) and phoratoxon sulphoxide (II).

て酸化的に代謝される. 2 種の土㙵線虫の内, Panagrellus redivivus からは phorte sulfoxide が, Aphelenchus avenae からは phoratoxon sulfoxide (Fig. 24-II) が得 られ，両代謝物は光学活性であった。また，Bacillus megaterium と Aspergillus niger も光学活性（一) な phorate sulfoxide 与劣たが，線虫からの代謝物とは旋 光度が逆であった ॠ $^{36)}$.

これらの事実は哺乳動物だけでなく, 線虫やその他の 微生物比よっも立体選択的に代謝が行なわれ，しか も，選択性は生物種によって異なっていることを示して いる.

(補) 最近, Lee ${ }^{42)}$ らは Dyfonate 光学異性体のマウス
肝 mfo による oxon 体への酸化が立体保持で進 行するとの結果を得ている。

\section{おわりに}

冒頭に述べたように，有機リン化合物は構造を改变す ることによって優れた生理活性を有する化合物を見いだ すことができ,その作用性はきわめて変化に富えでいる。 したがって，今後も有用な化合物を求めて種々のスクリ ーニングテストで続けられるであろう。しかしながら， 西る種の化合物は遅延性神経毒性 ${ }^{37,38)}$, 催奇形性 ${ }^{39)}$, 突

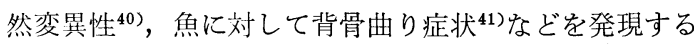
恐れもあり，まったくそれらの危険性がないわけではな い. 有機リン光学異性体に関しては, in vitro での酵素 反応，生物活性，哺乳動物に対する毒性，生体内代謝な ぞにおいて立体特異性の存在することが示された。 今後 さらに多くの有機りン光学異性体について広範囲の効力 や毒性テストを行なうことによって，より有害作用の少 ない化合物を発見できる可能性もあるだろう。

農薬として使用されている化合物の内には Dyfonate ${ }^{\circledR}$, Salithion®, EPN, Malation, Surecide® な゙゙多くの化合 物が不斉原子を持っており，鏡像体が存在する，それら は現在ラセミ体として使用されているが，光学活性体に 分割することにより効力が增すことは十分考えられる. また，ラセミ体を使用するよりも有用な異性体のみを農 薬として使用すれば，環境污染や有害作用の危険性をよ り少なくできるだろう。そのためには，有機リン光学異 性体の優れた立体選択的合成法や経済的な製法に関する 研究の進歩を伴わ祆ばならない。

\section{謝辞}

有機リン光学活性体の研究に種々の助言をしていただ きました本論文の発表の機会を与えていただいた住友化 学農薬研究部宮本純之主席研究員に深謝いたします。ま た，本論文を作製するに当たり資料集めなど種々の助力 をしていただいた三上信可研究員に感謝いたします。

\section{引 用 文 献}

1）宮本純之：防虫科学 36，135（1971）

2) M. Eto: "Organophosphorus Pesticides; Organic and Biological chemistry," CRC Press, Ohio, 1974

3) C. Fest \& K.-J. Schmidt: "The Chemistry of Organophosphorus Pesticides," Springer-Verlag, New York, 1973

4) J.E. Casida: Ann. Rev. Biochem. 42, 259 (1973)

5) K. Kakiki, T. Maeda, H. Abe \& T. Misato: Nippon Nogei Kagaku Kaishi 43, 37 (1969)

6) M. Eto \& H. Ohkawa: "Biochemical Toxicology 
of Insecticides," ed. by R.D. O'Brien \& I. Yamamoto, Academic Press Inc., New York, p. 93, 1970

7) S. Sumida \& M. Ueda: "Mechanism of Pesticide Action," ed. by G.K. Kohn, American Chemical Society, Washington, D.C. p. 156, 1974

8）上杉康彦，塚野 豊，松中昭一，見里朝正，宮本 純之: 化学総説 No. 2 (生態学の展望), 日本化 学会編, 東京大学出版会, p. 57, 1973

9) J. Meisenheimer \& L. Lichtenstadt: Chem. Ber. 44, 356 (1911)

10）向山光昭：“新しい有機合成反応”，広川書店，東 京, p. 21，1968

11) H.S. Aaron, T.M. Shryne \& J.I. Miller: J. Am. Chem. Soc. 80, 107 (1958)

12) H.S. Aaron, H.O. Michel, B. Witten \& J.I. Miller : J. Am. Chem. Soc. 80, 456 (1958)

13) D.A. Wustner \& T.R. Fukuto: J. Agr. Food Chem. 21, 756 (1973)

14) G. Hilgetag \& G. Lehmam: J. Prakt. Chem [4] 8, 224 (1959)

15) A.J.J. Ooms \& H.L. Boter: Biochem. Pharmacol. 14, 1839 (1965)

16) J.N. Seiber \& H. Tolkmith: Tetrahedron 25, 381 (1969)

17) J. Michalski \& M. Mikolajczyk: Tetrahedron 22, 3055 (1966)

18) H. Ohkawa, N. Mikami, A. Mine \& J. Miyamoto: Agr. Biol. Chem. 39, 2265 (1975)

19) R. Allahyari: PhD. Dissertation, University of California at Riverside, 1975

20) A.W. Herriott: J. Am. Chem. Soc. 93, 3304 (1971)

21) A. Hassan \& W. C. Dauterman: Biochem. Pharmacol. 17, 1431 (1968)

22) H. Ohkawa, N. Mikami, K. Kasamatsu \& J. Miyamoto: Agr. Biol. Chem. 40, 1857 (1976)

23) C.R. Hall, T.D. Inch, G.J. Lewis \& R.A.
Chittenden: J. Chem. Soc. 1975, 720

24) H.L. Boter \& C. van Dijk: Biochem. Pharmacol. 18, 2403 (1969)

25) T.R. Fukuto \& R.L. Metcalf: J. Econ. Entomol. 52, 739 (1959)

26) H.L. Boter \& A.J.J. Ooms: Biochem. Pharmacol. 16, 1563 (1967)

27) D.A. Wustner \& T.R. Fukuto: Pestic. Biochem. Physiol. 4, 365 (1974)

28) Y.C. Chiu \& W.C. Dauterman: Biochem. Pharmacol. 18, 359 (1969)

29) T.W. Holmsen: Weed Sci. 17, 187 (1969)

30) H. Tolkmith, J.N. Seiber \& P.B. Budde: Science 158, 1462 (1967)

31) J.N. Seiber \& H. Tolkmith: Tetrahedron Letters 34, 3333 (1967)

32) P.J. Cox, P.B. Farmer, M. Jarman, M. Jones, W.J. Sec \& R. Kinas: Biochem. Pharmacol. 25, 993 (1976)

33) H. Ohkawa, N. Mikami \& J. Miyamoto: Agr. Biol. Chem. 40, 2125 (1976)

34) R.L. Metcaef, T.R. Fukuto \& R.B. March: J. Econ. Entomol. 50, 338 (1957)

35) J.E. Casida, E.C. Kimmel, H. Ohkawa \& R. Ohkawa: Pestic. Biochem. Physiol. 5, 1 (1975)

36) G.N.J. LePatourel \& D.J. Wright: Comp. Biochem. Physiol. 53, 73 (1976)

37) M.K. Johnson: Arch. Toxicol. 34, 259 (1975)

38) M.T. Abou-Donia \& S.H. Preissig: Toxicol. Appl. Pharmacol. 35, 269 (1976)

39) N.H. Proctor, A.D. Moscioni \& J.E. Casida: Biochem. Pharmacol. 25, 757 (1976)

40) M.J. Ashwood-Smith, J. Trevino \& R. Ring: Nature 240, 418 (1972)

41) 金沢 純: 科学 46, 108 (1976)

42) P.W. Lee, R. Allaphari \& T.R. Fukuto: Biochem. Pharmacol., submitted 